\title{
Long-term and High Temporal Resolution in Situ Monitoring of Potassium, Sodium, and Chloride in a Small Forested Catchment Using Flow Injection Potentiometry
}

\author{
Akio TADA ${ }^{1)}$ Haruya TANAKAMARU 1) Takeshi HATA 2) \\ 1) Faculty of Agriculture, Kobe University \\ (1-1 Rokkodai, Nada, Kobe, 657-8501) \\ 2) Emeritus professor of Kobe University \\ (249-11 Miyakecho, Iwakura, Sakyo, Kyoto, 606-0022)
}

\begin{abstract}
Long-term water quality data with high temporal resolution, together with hydrological data, are essential in developing hydrogeochemical and diffuse pollution modeling. An in situ flow injection potentiometry (FIP) system to monitor the stream water quality (chloride, sodium and potassium) every 15 minutes for two weeks was developed and tested in the laboratory and in a small forested catchment in Gozyo City, Nara Prefecture, JAPAN. The system resolves main hurdles that prevent long-term monitoring, except the problem of samples freezing in winter. Frequent calibration with three standards was adopted to compensate for the temperature dependency of ion-selective electrodes. The results of monitoring stream water quality in this catchment in 2004 showed clear differences in the concentration of the ions of chloride, potassium, and sodium depending on discharge: chloride showed the simple washout of accumulated atmospheric input, potassium implied the washout from the stock in the shallow soil layer, and sodium indicated the effect of ion exchange and chemical weathering.
\end{abstract}

Key words: In situ monitoring; Flow injection potentiometry; Stream water chemistry; Long-term monitoring; Ionselective electrode

\section{I . INTRODUCTION}

Flow Injection (FI) analysis is an automated method of analyzing water quality using pumps, tubes, and valves (Růžička et al., 1988). In the FI method, a detector is chosen depending on target indices and the analytical methods. Because of the wide range of the customization of analytical circuits, the possibility of miniaturizing total analytical system, and high analytical frequency, FI devices are widely used in analytical chemistry. Application of the FI method to environmental monitoring is also a trend in analytical chemistry. Numerous studies on environmental monitoring techniques using the FI method have been made (Worsfold et al., 1987; Motomizu et al., 1997); however, studies on water quality based on such monitoring are still few. For long-term monitoring, FI devices have just come out of the laboratory and into actual field sites (Benson et al., 1996a, b; Hanrahan et al., 2001; Coles et al., 2003) although long-term monitoring of marine water has been in practice for some time (Gardolinski et al., 2002; Lyddy-Meaney et al., 2002; Bowie et al., 2002). In such studies, "longterm" usually means not several weeks or months but several days. However, "long-term" usually means several months to several years in hydrology. Flow injection potentiometry (FIP) using ion-selective electrodes (ISEs) is one of the most practical approaches for monitoring water 
quality because of the simplicity of the detector and for providing a wide range of measurements (Dimitrakopoulos et al., 1996; Alexander et al., 1996; De Macro et al., 2003).

With regard to water quality in hydrogeochemistry and in diffuse pollution, lack of continuous data from long-term monitoring of water quality has hindered the progress of water quality modeling because of the difficulty of calibrating simulated values against observed ones with sufficient temporal resolution (Neal et al., 2000). Also, overparameterization is a common problem in water quality modeling (Robson et al., 1995).

In both hydrogeochemical and diffuse pollution studies, the appropriate temporal resolution for monitoring the catchment water quality is around 10 to 60 minutes depending on the scale of the catchment and the frequency of its hydrological response. In small catchments within about 10 $\mathrm{km}^{2}$, other than urban ones, a 10-to30-minute resolution is appropriate (Hanrahan et al., 2001). More frequent temporal resolution is not essential because the temporal resolution of hydrological data is limited to 5-10 minutes.

For hydrogeochemical purposes, indices of silica, chloride, and sodium, which are considered conservative tracers (e.g. Kennedy et al., 1986; Yuretich et al., 1988, Neal et al., 2000), are useful for the estimation of water movement or water budget in catchments. In such studies, mass flux budget such as sodium and chloride between input and output in/out of the catchment is balanced, although an excess of sodium export compared with input is commonly reported in Japanese forested catchments (Tokuchi et al., 1991, Kaneko, 1998). In all the above studies, chloride is considered a conservative tracer, although sodium reflects the effects of ion exchange in soils and chemical weathering in bed rocks. The difference of those two indices in temporal fluctuation might provide hydrological information of the water path in the catchment. Conversely, accumulated potassium, nitrate, calcium and magnesium in surface layers of forest ecosystems have been reported in comparison with conservative indices such as silica, sodium and chloride, and the different responses between them, in response to runoff, has been described (Muraoka et al., 1988).

Therefore, the present study was firstly aimed at developing, with the FIP technique, an in situ, continuous, long-term, and precise water quality data acquisition system, designed on the serial array of ISEs proposed by Dimitrakopoulos et al. (1996). Here, "long-term" indicates two weeks of analysis since duration such as one or two weeks is considered the shortest term because of the need for equipment maintenance in acquiring data for more than several months. Chloride, potassium and sodium were the observed indices in this system. Secondly, temporal fluctuations and responses in concentrations of the solutes in the stream water were compared with rainfall and discharge to deduce the characteristics of the hydrogeochemical responses in the catchment on the basis of water quality data by high temporal resolution.

\section{Experiments}

\section{Field study site}

A small forested catchment (12.82 ha; mainly Japanese cedar and pine) in Gozyo City, NARA prefecture, Japan was chosen as the target site (Fig.1), with the bed rock comprising low permeable metamorphic rock overlaid with

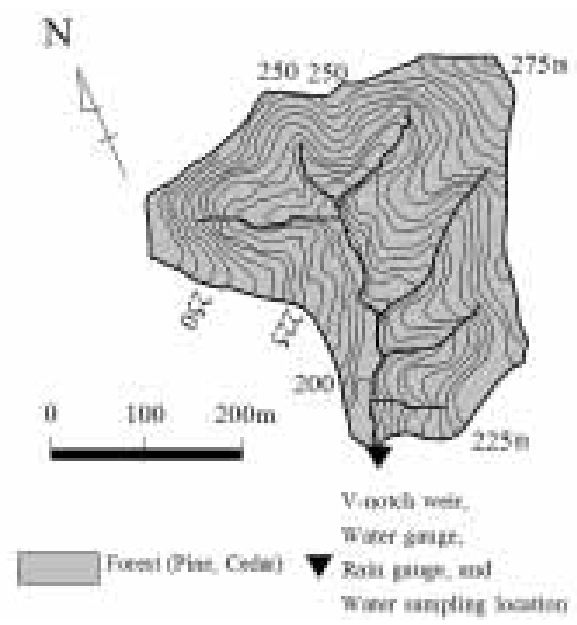

Fig. 1 Field study site. 
permeable diluvial and alluvial deposits. Discharge has been gauged since 1980 with a Vnotch weir set at the outlet of the catchment. Because the weir is placed directly on the bedrock, all discharge components including groundwater flow are assumed to be measured. The amount of precipitation has also been measured at the same location.

From 1991 to 1993, the concentration of suspended solids ranged between 0.1 and $2.0 \mathrm{mg} / 1$ at low flow and over $150 \mathrm{mg} / \mathrm{l}$ at high flow, and $\mathrm{pH}$ ranged between 5.4 and 6.5. Suspended solids at high flow consisted mainly of silt and small litter (Tada et al., 1996).

The water quality data discussed in this study was collected from $5^{\text {th }}$ March to $8^{\text {th }}$ December 2004, using the FIP system described below. The bulk precipitation outside the forest canopy was also collected at the V-notch weir and analyzed.

\section{Reagents and standards}

All chemicals used were of analytical reagent grade. Deionized distilled water with electrical conductivity of less than $0.1 \mu \mathrm{S} / \mathrm{cm}$ was used. A $0.007 \mathrm{M} / \mathrm{L}$ lithium acetate solution was used as a carrier because of the low selectivity coefficient for lithium to ISEs (Dimitrakopoulos et al., 1996). Standard solutions of potassium, chloride, and sodium were prepared by diluting potassium chloride and sodium chloride with distilled water.
The concentrations of the three standards were set at $0.2,0.6,1.0 \mathrm{mg} / 1$ for potassium, $0.3,1.0$, and 4.0 $\mathrm{mg} / \mathrm{l}$ for sodium, and $0.644,2.086$, and $7.07 \mathrm{mg} / 1$ for chloride, on the basis of previous studies at the same site (Tada et al., 1996). The standard solutions placed at the site for two weeks demonstrated no significant change in concentration.

\section{Instrument design}

\section{1) System overview}

The system of in situ FIP monitoring comprised two main units (Fig.2): the FIA flow conditioning unit (FIA-F) and the stream water sampling unit (FIA-S). The objective of the design was automated monitoring for two weeks without any maintenance. The cycle of samplings was set at 15 minutes, which was determined mainly by electric power consumption for two weeks and by the dispersion in the flow-through cells.

\section{2) Detector and data recorder}

The detector ISEs were arrayed with potassium ISE (7421L, DKK TOA, JAPAN), chloride ISE (7021L, DKK TOA), and sodium ISE (7481L, DKK TOA). The sensing membranes of potassium and sodium were liquid-based polymers. The ionophores were valinomycin for the potassium ISE and Bis (12-crown-4) for the sodium ISE. The chloride ISE had a solid sensing membrane that was based on a mixture of silver chloride and

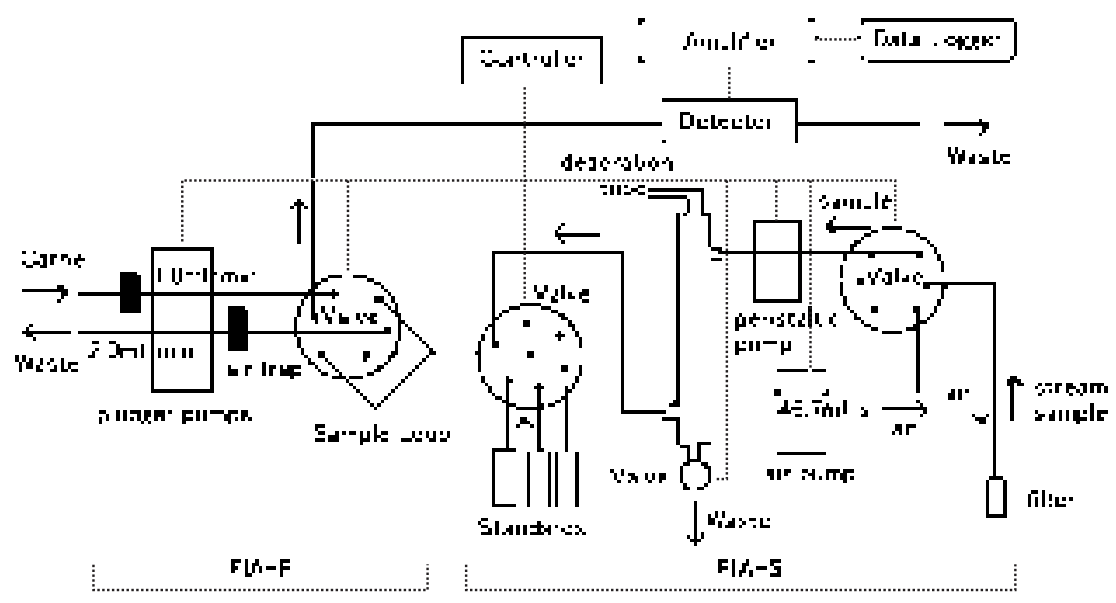

Fig. 2 FIA flow unit (FIA-F) and stream water sampling unit (FIA-S). 
silver sulphide. The limits of determination for the ISEs were $0.4,0.2$, and $1.8 \mathrm{mg} / 1$ for potassium, sodium, and chloride, respectively. The measurable $\mathrm{pH}$ of all ISEs ranged between 5.0 and 8.0. The range of $\mathrm{pH}$ in the stream water previously mentioned caused no significant change in the raw potential value of the ISEs.

All ISEs were attached to flow-through cells (DKK TOA FLC-11 for chloride, FLC-12 for the others) connected with $1 \mathrm{~mm}$ ID Teflon tubes. DKK-TOA 4401L was used as the reference electrode with a single, not double, porous polytetrafluoroethylen (PTFE) junction. The advantage of this reference electrode was longterm stability (Ito et al., 1996).

The electrical potential from the ISEs was measured with a DC powered amplifier, with a sufficient input impedance of $10^{11} \mathrm{ohms}$. The ISEs and the amplifier were connected with a differential cable. This differential connection was essential for minimizing noise in the potential signal. The output from the amplifier was collected in a solid-state data logger equipped with a PCMCIA compact card slot (NR-1000, Keyence, JAPAN). A 48MB PC card was large enough to store the data for two weeks with a $500 \mathrm{~ms}$ sampling rate of the ISE potential value.

\section{3) Flow injection manifold}

FIA-F, the pump system for flow injection analysis, consisted of two plunger pumps and one 6 -port valve. A sample loop of $2.0 \mathrm{ml}$ was connected to the two ports of the valve. The 6-port valve was used to switch the flow circuit for the sample and carrier streams. A single plunger pump introduced the sample stream into the loop at a flow rate of $2.0 \mathrm{ml} / \mathrm{min}$. A double plunger pump sent the carrier and sample streams to the ISEs at a flow rate of $1.0 \mathrm{ml} / \mathrm{min}$.

FIA-S, the stream water sampling system that prevented filter clogging and sample contamination, consisted of one 1-6-port valve, one 6-port valve, one peristaltic pump, and one air pump. The timings of switching the flow circuit and starting/stopping the pumps in both FIA-S and
FIA-F were operated by the controller inside FIAS. All timings and flow rates of the pumps were programmable.

The sampling filter (about $10 \mathrm{~mm}$ pore; SUSsolvent filter, Tomsic, JAPAN) was set directly inside the V-notch weir. To prevent clogging of the filter by suspended solids for two weeks, the air pump blew air to the sampling filter (for 7 seconds just before every sampling). The flow rate of the air pump was $46.7 \mathrm{ml} / \mathrm{s}$, with a flow pressure of $2.5 \mathrm{f} / \mathrm{cm}^{2}$. The 6-port valve switched the flow circuit for blowing air and for sampling.

The stream water sample was first introduced into a glass tube (deaeration tube) by the peristaltic pump for 70-80 seconds at a flow rate of $8 \mathrm{ml} / \mathrm{min}$, stored for several seconds to remove the air (no trace in high flow periods) remaining in the sample, and then introduced to the ISEs in the FIA-F. The deaeration tube was then cleared of remaining excess water and rinsed with fresh stream water before storing the sample.

The three different standard solutions were automatically analyzed periodically to update the calibration curve. The 1-6-port valve was used to switch the flow circuit among the three standards and the sample. FIA-S could handle up to five standards.

\section{4) Power supply}

The following $12 \mathrm{~V}$ DC batteries were used for continuous in situ monitoring for two weeks: four 88Ah batteries (GET-120E41R, Japan storage battery Co., JAPAN) for FIA-S and FIA-F; four 88Ah batteries (GET-100E41R) for the amplifier; and one 64Ah battery (GET-105E31R) for the data logger. The batteries ran the system for 15 days on average.

\section{Batch method}

Capillary electrophoresis (CE) analysis (Quanta $4000 \mathrm{E}$, Waters, U.S.A.) was used for determining the concentrations of stream grab samples just before shutdown and after the start of the system, and then filtered in the laboratory. It was also used for checking the concentrations of the standards. 


\section{Results and Discussion}

\section{Calibration formula}

The Nernst equation (Eq.1), commonly used for the calibration curve in the FIP system, requires two parameters;

$$
E=a \log C+b
$$

where $a$ is the electrode slope $[\mathrm{mV} /$ decade $] ; b$, the standard potential $[\mathrm{mV}] ; E$, the peak potential of ISEs $[\mathrm{mV}] ; C$, the concentration $[\mathrm{mg} / \mathrm{L}]$. Table 1 shows good regression by this equation in this system $\left(\mathrm{R}^{2}\right.$ of regression with Eq. 1 ranges from 0.997 to $0.999, n=4,4$ and 3 for sodium, potassium and chloride, respectively). The electrode slope was drawn according to the following equation;

$$
a=\frac{2.303 R T}{z F}
$$

where $R$ is the gas constant $\left[\mathrm{JK}^{-1} \mathrm{~mol}^{-1}\right] ; T$, the absolute temperature $[\mathrm{K}] ; F$, the Faraday constant $[\mathrm{C}]$; and $z$, the valence of the ion.

\section{Method for temperature compensation}

ISE peak potential values changed depending mainly on cell temperature, which was difficult to measure because of the lack of temperature compensation probes in the ISEs. To precisely determine the sample concentration with the use of ISE potential, the temperature dependency of ISE potential was compensated and the Nernst equation was calibrated for each sample.

Fig. 3 shows the fluctuation in the raw potential of the potassium ISE attributed to the dependency of ISE on temperature. The square boxes represent the peak potential values for the standards, and the dotted lines represent base line (carrier) potential values. Although a rough correlation between the peak ISE potential values for standards and the sample (stream) temperature was observed, it was difficult to precisely estimate this correlation because there was a time lag between peaks/ bottoms in the temperature of samples and the values of ISE potential caused by the temperature

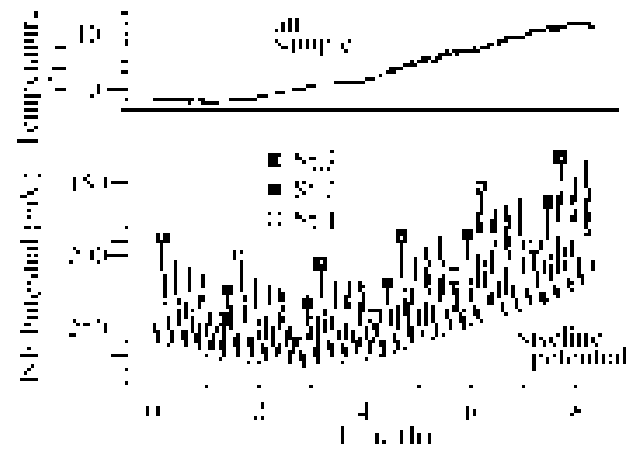

Fig. 3 Fluctuation of potassium ISE potential due to temperature dependency.

Table 1 Precision of typical flow injection peaks for potassium, sodium and chloride ISE array

\begin{tabular}{|c|c|c|c|c|}
\hline Indices & Number of samples & $\begin{array}{c}\text { Standard } \\
\text { Concentration }(\mathrm{mg} / \mathrm{l})\end{array}$ & $\begin{array}{c}\text { Peak Potential } \\
\text { Values }(\mathrm{mV})[\% \text { RSD] }\end{array}$ & $\begin{array}{l}\text { Electrode Slope } \\
\text { (mV/decade) [SD] }\end{array}$ \\
\hline \multirow{4}{*}{$\mathrm{K}^{+}$} & 4 & 0.2 & $172.0[0.3]$ & \multirow{4}{*}{$65.6[0.9]$} \\
\hline & 4 & 0.5 & $192.5[0.2]$ & \\
\hline & 12 & 0.6 & $198.3[0.4]$ & \\
\hline & 4 & 1.0 & $211.1[0.3]$ & \\
\hline \multirow{4}{*}{$\mathrm{Na}^{+}$} & 4 & 0.3 & $-132.5[0.2]$ & \multirow{4}{*}{$61.7[0.2]$} \\
\hline & 4 & 1.0 & $-82.1[0.0]$ & \\
\hline & 12 & 2.0 & $-47.9[0.4]$ & \\
\hline & 4 & 4.0 & $-15.6[1.9]$ & \\
\hline \multirow{4}{*}{$\mathrm{Cl}^{-}$} & 4 & $0.644 *$ & $400.7[0.0]^{*}$ & \multirow{4}{*}{$-58.6[2.4]$} \\
\hline & 4 & 2.086 & $391.6[0.4]$ & \\
\hline & 12 & 3.535 & $379.8[0.0]$ & \\
\hline & 4 & 7.07 & $364.2[0.4]$ & \\
\hline
\end{tabular}
(temperature is $22.0{ }^{\circ} \mathrm{C}$ and stable).

$\mathrm{RSD}=$ relative standard deviation $; \mathrm{SD}=$ standard deviation

*; not included in determination of electrode slope. 
Table 2 Results of the stability test.

\begin{tabular}{l|c|c|c|c|c|c}
\hline \multirow{2}{*}{} & \multicolumn{3}{|c|}{ Laboratory test $(\mathrm{n}=315)$} & \multicolumn{3}{c}{ field test $(\mathrm{n}=135)$} \\
\cline { 2 - 7 } & $\mathrm{K}^{+}$ & $\mathrm{Na}^{+}$ & $\mathrm{Cl}^{-}$ & $\mathrm{K}^{+}$ & $\mathrm{Na}^{+}$ & $\mathrm{Cl}^{-}$ \\
\hline Concentration (mg/l) & 0.50 & 2.00 & 3.54 & 0.60 & 1.77 & 2.99 \\
Measured (mg/l) & 0.46 & 2.03 & 3.25 & 0.56 & 1.79 & 2.99 \\
RSD (\%) & 6.20 & 3.54 & 1.60 & 7.59 & 0.80 & 1.82 \\
\hline
\end{tabular}

$\mathrm{RSD}=$ relative standard deviation.

Table 3 Effect of the calibration intervals on measured concentration $(n=378)$.

\begin{tabular}{c|c|c|c|c|c|c|c}
\hline \multirow{2}{*}{ Indices } & \multirow{2}{*}{$\begin{array}{c}\text { Concentration } \\
(\mathrm{mg} / \mathrm{l})\end{array}$} & \multicolumn{2}{|c|}{ Calibration intervals } \\
\cline { 3 - 8 } & & \multicolumn{2}{|c|}{$1.5 \mathrm{~h}$} & \multicolumn{2}{|c|}{$3 \mathrm{~h}$} & \multicolumn{2}{c}{$6 \mathrm{~h}$} \\
\cline { 3 - 8 } & & Av. $(\mathrm{mg} / \mathrm{l})$ & RSD $(\%)$ & Av. (mg/l) & RSD (\%) & Av. (mg/l) & RSD (\%) \\
\hline $\mathrm{K}^{+}$ & 0.755 & 0.714 & 5.89 & 0.717 & 8.14 & 0.714 & 12.7 \\
$\mathrm{Na}^{+}$ & 2.010 & 1.966 & 2.17 & 1.974 & 2.62 & 1.963 & 3.01 \\
$\mathrm{Cl}^{-}$ & 3.615 & 3.578 & 1.87 & 3.582 & 2.04 & 3.582 & 2.10 \\
\hline
\end{tabular}

$\mathrm{RSD}=$ relative standard deviation.

difference in the stream and in the ISE cell. On the other hand, the peak potential values for standards showed good linear correlation with the base line potential value during short periods such as 24 and 36 hours (usually $\mathrm{R}^{2}$ of linear regression between them ranged from 0.96 to 0.99 ) because both potential values were affected by the same temperature in the ISE cell. Consequently, the peak potential values for standards were estimated from the base line potential by linear regression. Since the peak potential values of the standards at every sampling were estimated from the base line potential, the Nernst equation was calibrated for each sample.

\section{Laboratory and field trial results}

In the temperature compensation method above, the cycle of the calibration with three standards was determined, and the stability of the measured concentration with temperature fluctuation was confirmed. To verify the stability, the constant concentration test was carried out both in the laboratory and in the field. In each test, artificial samples of constant concentration were prepared as test samples.

Laboratory tests were carried out for three days, under air temperatures ranging between 20 and $30{ }^{\circ} \mathrm{C}$ with a weak diurnal cycle (Table 2). The values of peak potentials and the electrode slope in Table 1 were obtained under constant temperature.
The field test was carried out twice; the first for 3 days under air temperatures between 2 and $10{ }^{\circ} \mathrm{C}$ with a diurnal cycle and a calibration cycle of 1.5 hours (Table 2). The second field test was carried out for 8 days under air temperatures between 3.2 and $24.5{ }^{\circ} \mathrm{C}$ with a strong diurnal cycle (Table 3) and the effect of the calibration cycle on calculated concentration values was also evaluated. Fig.4 shows the results for sodium.

Shorter calibration cycles showed smaller relative standard deviations (RSD) in concentration (Table

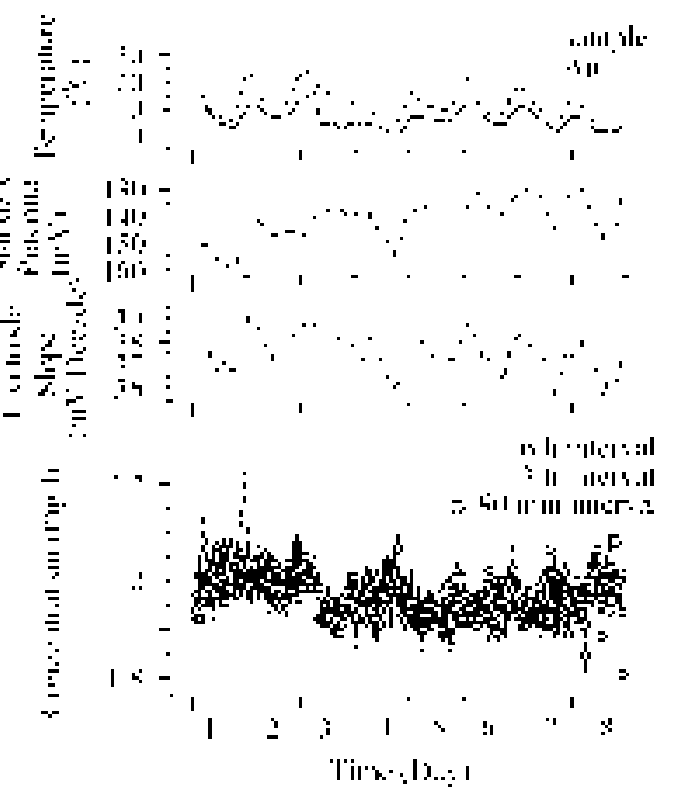

Fig. 4 Measured concentration of sodium in the field test. 
3). For potassium, a weak correlation was observed between temperature and concentration even with 90-minute calibration cycles. Relatively high RSD values of potassium in Table 3 reflected this weak correlation. For sodium and chloride, the RSD values were small enough for all cycles (Table 3 and Fig.4). Fig. 4 also shows how temperature fluctuation was compensated by the parameters in Eq.1. The electrode slope and the standard potential as in Eq.2 increased with an increase in temperature. Although temperature compensation was not complete for potassium, the results were acceptable for sodium and chloride (Table 3).

The reason for the high temperature dependency of ISE was mainly the order of the ISE array. The ISE order in the array and the order of the gap between the maximum and the minimum base line potential were consistent, implying that temperature fluctuations in the samples and the carrier became mild as the samples and the carrier flowed in the ISE array. Since it was difficult to keep the temperature in the ISE constant in the field, the fluctuations in the base line potential remained high. More frequent calibration might be practical for precisely determining potassium concentration.

\section{Comparison of measured concentrations by FIP system with those by batch method}

The concentrations in the stream samples were compared between the FIP system and CE analysis (Fig.5). The concentrations by both assays showed a reasonable agreement, taking the analytical deviation (precision) into consideration, although the concentrations by $\mathrm{CE}$ analysis tended to be slightly higher than those by the FIP system. This was caused by the suspended solids in the grab samples. Thereafter, the grab samples were filtered in situ through a $1.0 \mu \mathrm{m}$-pore glass-fiber filter.

\section{Problems and prerequisites of long-term monitoring}

To achieve long-term, high temporal resolution monitoring of the quality of stream water, prevention of filter blockage and of the inflow of air to the sample flow line was essential. Even in low flow periods when the concentration of suspended solids was usually under $2.0 \mathrm{mg} / \mathrm{l}$, filter clogging occurred within three or four days in the absence of an air pump. Filter clogging became almost negligible for two weeks after the addition of an air pump to the system. Also by adopting the deaeration tube, no air reached the ISEs even in high flow periods when stream water contained large amounts of suspended solids and air.

Sample freezing around the deaeration tube walls during low temperatures (under $-4{ }^{\circ} \mathrm{C}$ ) remains unresolved, however. Once freezing occurred, the sample pump did not move the stream sample because of the ice plug, and the pump stopped in turn. No stream data were collectible after the freezing.

Frequent automatic cyclic calibration was also very effective in keeping the monitoring results accurate. The temperature dependency of the sensor or the detector is inevitable for in situ monitoring. Although the 6-hour calibration cycle was acceptable for the relative standard deviation values of chloride and sodium (Table 3), even the 90-minute calibration cycle was not sufficient for potassium to compensate for the temperature dependency of ISE, considering the three-fold standard deviation and the results in Fig.5.

Although the individual methodology adopted

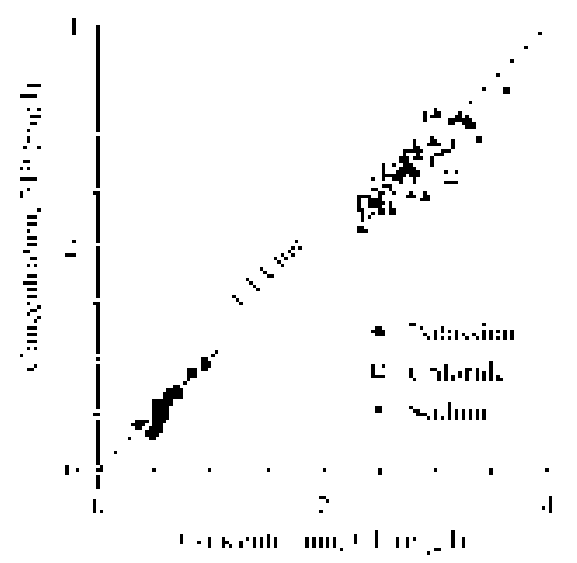

Fig. 5 Comparison of stream sample concentrations between FIP method and CE analysis. 
and the characteristics of the target sample were completely different, the incorporation of a deaeration device, frequent calibration and filterblockage treatment coincided with the system for wastewater of Benson et al. (1996a, 1996b). These three functions were considered requisites for high temporal resolution and long-term monitoring even in a forested catchment.

\section{Field observation results}

For monitoring water quality at the study site, a 15-minute sampling cycle and a 6-hour calibration cycle were adopted. This resulted in a slight fluctuation only in the concentration of potassium. Hydrologic and water quality monitoring was carried out from March to December 2004 (Fig. 6). No obvious seasonal trends and temperature dependencies in concentration were identified in any of the indices (Fig.6). To increases in discharge, sodium showed a negative (dilution) response and potassium concentration a positive one, whereas chloride concentration showed positive, negative, and flat responses. These results indicated that concentration responses were determined mainly not by temperature but by discharge, although data for mid winter were lacking. Some periods of interrupted monitoring

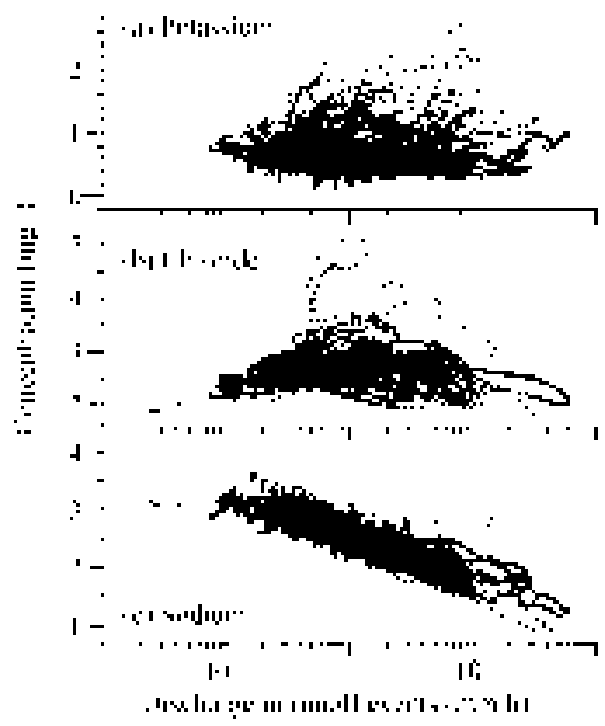

Fig. 7a Concentration - discharge relation (in runoff events).
(Fig.6) were due mainly to the deterioration of batteries and power cables.

Fig.7a shows the relation between concentration and discharge in runoff events, and Fig.7b shows the relation between them in low flow periods
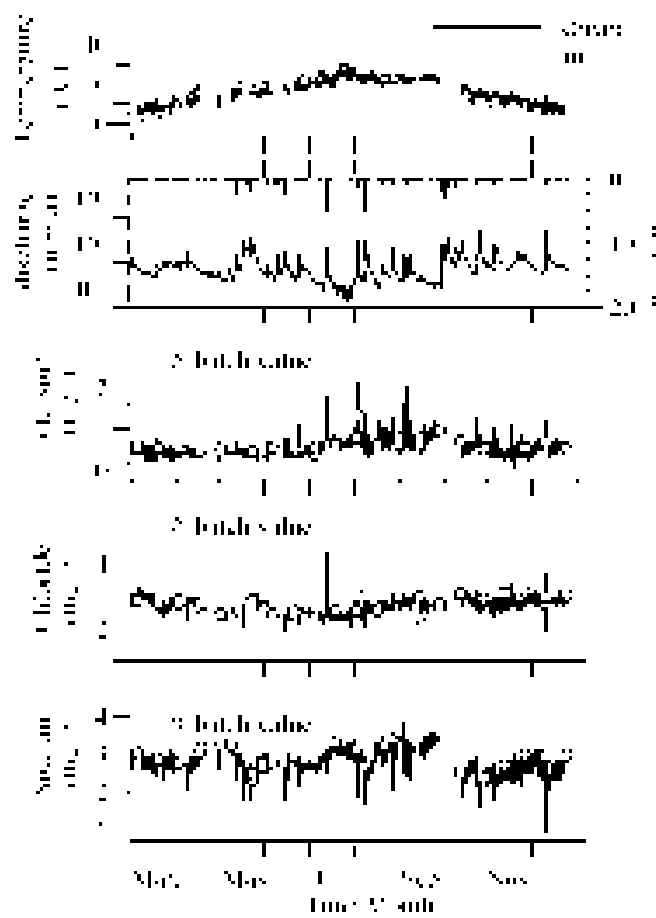

Fig. 6 Field monitoring results in 2004.

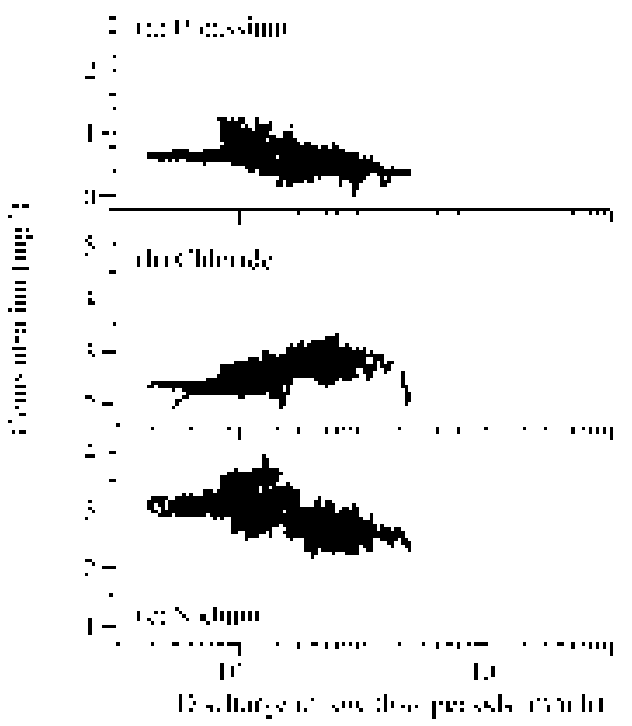

Fig. 7b Concentration - discharge relation (in low flow periods). 
(actually non-runoff event periods). The distinction between runoff events and non-runoff events was determined by the base flow separation technique using a numerical filter (Lyne et al., 1979; Arnold et al., 1995; Tada et al., 2006). Only sodium concentration clearly displayed a negative response to increases in discharge (Fig.7 $\mathrm{a}$ and b). On the other hand, the response of potassium and chloride concentration to discharge was not apparent in runoff events (Fig.7a). One of the reasons for this ambiguous response was the hysteretic loop in concentration to discharge plot during runoff events: a clockwise loop for positive correlation and a counterclockwise loop for negative correlation. These loops produced the scatterings seen in Fig.7a. To analyze the response of concentration to discharge in detail, the average difference in concentration between the value at the beginning of runoff and the values during the rising limb in the runoff discharge $(\Delta \mathrm{C})$ was evaluated from all observed runoff events $(\mathrm{n}=51)$. The histograms of $\Delta \mathrm{C}$ clearly displayed the different responses of these three indices to runoff events (Fig.8). The decrease in sodium and the increase in potassium concentration during runoff events were generally recognized; however, no apparent tendency was observed in the chloride response to runoff events. Increases in discharge during low flow periods affected the concentration differently (Fig.7b). The concentration of chloride

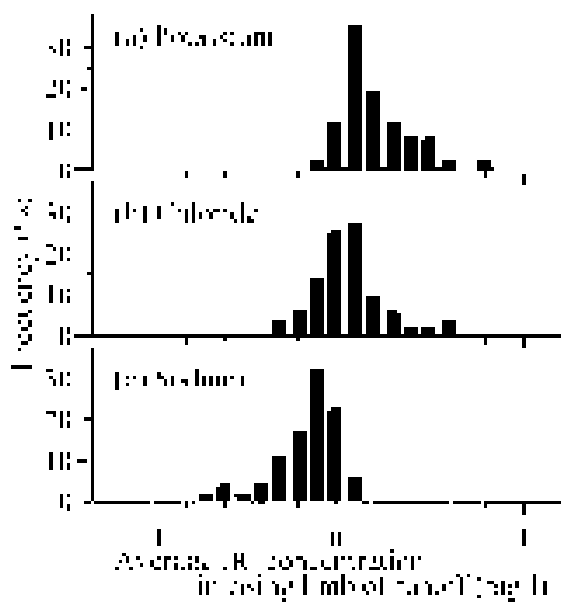

Fig. 8 Histograms of average $\Delta \mathrm{C}$ in rising limb of runoff event. showed a weak positive correlation with discharge, and the concentrations of sodium and potassium showed weak negative correlations, although concentrations of all the indices were almost constant during extreme low flow periods under $0.0122 \mathrm{~mm} / \mathrm{h}$ (the value of $10 \%$ frequency from the minimum discharge).

The effect of discharge on concentration during October 2004 showed typical patterns of concentration for potassium and sodium in the catchment (Fig.9):potassium generally demonstrated a rapid increase at the beginning of runoff events, indicating the effect of the stock in surface soil layer. Chloride showed a wide pattern of changes with its concentration being almost negligible (constant) during runoff events such as Fig.9 and increases/decreases during other runoff events. The decreases were accompanied with small rises at the beginning of runoff events.

During low flow periods, the tendency of decline in the concentrations of potassium and sodium indicated slow recovery from dilution or restricted release of solute from deeper layers of soil (Fig.7b). On the other hand, the tendency of

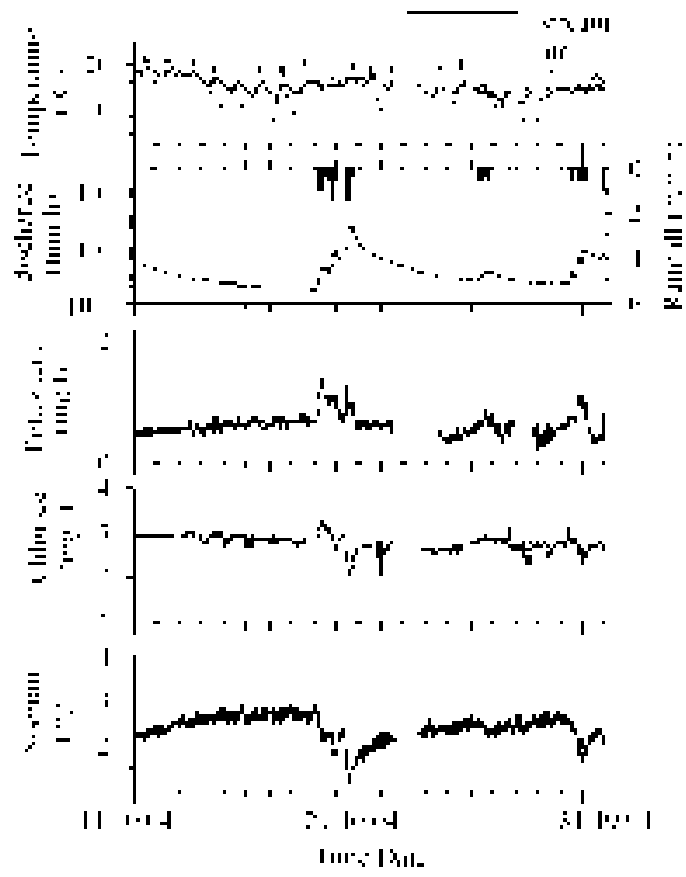

Fig. 9 Field monitoring results in October 2004. 
rise in the concentration of chloride indicated an abundant supply of solute from ambient circumstances, such as the capillary fringe area or upper soil layers. The soluble amount of chloride increases with soil depth, whereas the amount of soluble sodium is relatively small compared with that of chloride (Tokuchi et al., 1991). The discharged water was considered to pass through surface or shallow soil layers during high flow periods. The tendencies of concentration during increases of discharge (Fig.7a and Fig.8) reflected the availability or an abundance of solutes in surface or shallow soil layers: potassium consistently showed an increase, implying that the main source of potassium lay in shallow surface layers; sodium consistently showed a decline, indicating a poor supply of sodium in upper soil layers. Chloride showed all patterns of concentration in response to discharge increases, indicating that the availability and amount of solute in surface soil layers was highly variable, which may be attributed to amount of the atmospheric depositions in this catchment. The soluble amounts of the indices discussed here may support results of studies in the forested basin in the Tsukuba Mountains, where the concentration of potassium and chloride in surface and shallow soil layers is relatively high (Muraoka et al., 1988). The main source of chloride in natural forested catchments may be atmospheric depositions, which are not absorbed by the soil. These properties resulted in the availability of various amounts of chloride in shallow soil layers. The amount of chloride (Fig.9) reflects the washout of atmospheric depositions in surface and shallow soil layers in the first stage of the rising limb of the hydrograph and low availability after the washout at peak runoff and in the falling limb. The potassium response (Fig.9) suggested that the potassium source in the shallow soil layer was not depleted as quickly as chloride was.

Fig.10 shows the relation between sodium and chloride concentrations in stream water and bulk precipitation. The slope of the regression line for bulk precipitation was $0.515 \pm 0.0226\left(\mathrm{R}^{2}=0.917\right)$ and similar to the ratio in seawater $(0.557$, Stumm et al, 1996). The overall difference in chloride concentration between bulk precipitation and stream water was attributed to the portion of dry deposition accumulated in forest vegetation. The input of sodium and chloride in bulk precipitation outside the forest canopy were $43.4 \mathrm{~kg}$ and $89.0 \mathrm{~kg}$ for the whole catchment during the analysis period, the effluent load in stream water was 150.2 $\mathrm{kg}$ and $126.4 \mathrm{~kg}$, respectively. The impacted amount of chloride in forest vegetation was estimated to be at least $37.4 \mathrm{~kg}$. The ratio of sodium to chloride at low flow periods (about 1.3) was much higher than at bulk precipitation (Fig.10). This was attributed to the high contribution of the base flow component which contains rich sodium by ion exchange and chemical weathering. During runoff events, the ratio in stream water gradually reached the ratio in bulk precipitation regardless of how the chloride concentration changed. In this catchment, the concentration of chloride in the stream was usually low; therefore a decrease in the concentration of sodium because of the ion exchange might not have occurred. Both ion exchange and chemical weathering might have contributed to the increase in the ratio of sodium to chloride in the stream water, and it was difficult to distinguish between the contributions of the two mechanisms.

To evaluate the effect of ion exchange during

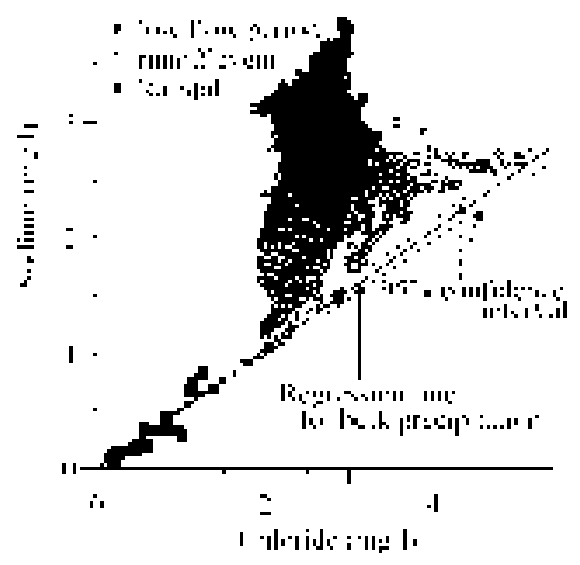

Fig. 10 Sodium - chloride relation in stream water and bulk precipitation. 


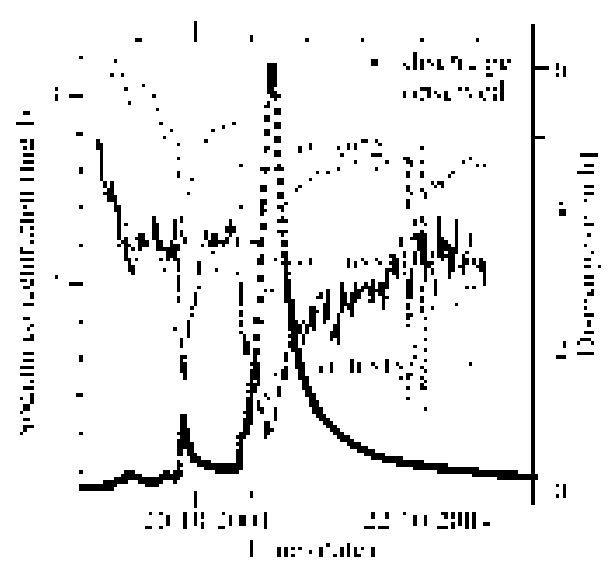

Fig. 11 Calculated sodium concentration from the different ratio of sodium to chloride in runoff load. dotted line; calculated sodium concentration using fixed $r t$ value.

runoff events, it was assumed that the runoff load had a fixed ratio of sodium to chloride. If the runoff load had been defined by the product of the increase in discharge and the difference in concentration from the beginning of the runoff event, the sodium runoff load would have been calculated from the product of the chloride runoff load and the fixed ratio of sodium to chloride $(r t)$ because chloride was considered a conservative ion. Fig. 11 shows the results of calculation for the same runoff event in Fig.9. The $r t$ value of 0.515 indicated that the ratio in all runoff loads was the same as that in bulk precipitation, and the value of 0.971 indicated that the ratio in all runoff loads was the same as that in stream water at the beginning of the runoff. These two cases implied extreme assumptions. The $r t$ value of 0.685 was determined so that the calculated concentration of sodium could match the observed concentration during the first day of the runoff event. In the case of $r t=0.685$, the increase in the observed concentration of sodium, compared with the calculated concentration, was recognized in the recession limb of the runoff hydrograph. This increase might be attributed to the higher ratio of the base flow to total discharge or to the contribution of ion exchange in the soil. The actual $r t$ value would be expected to decrease gradually as the runoff event proceeded because of rainfall infiltrating the soil layer. To compensate for the difference in the concentration of sodium between the calculated and observed values, the effect of ion exchange in the soil might be a more tenable reason considering the speed of reaction.

\section{Conclusions}

The FIP field monitoring system developed in this study enables the monitoring of stream water chemistry without maintenance for a period of two weeks.

To achieve long-term, high temporal monitoring of stream water quality, both prevention of filter blockage and removal of air from stream samples were essential. To remove air from the sample being analyzed was crucial because the filtered stream sample induced by the pump into the system included air caused by the clogging due to suspended solids and air in stream water during high flow periods. Frequent automatic cyclic calibration was also effective in keeping the monitoring results accurate and stable in spite of the temperature dependency of ISEs. The 6-hour cycle of the calibration for sodium and chloride was adequate, even though a 90-minute cycle was not sufficient for potassium.

Freezing of the water sample in the FI system was inevitable under low temperature. This problem remained in this system. Adding a heater and additional power supply to the system would enable year-round monitoring.

From the observations in the small forested catchment in 2004, the responses of the indices (potassium, sodium, and chloride) to discharge showed different characteristics. The potassium and sodium responses showed a weak negative correlation with discharge during low flow periods, indicating a slow recovery from the diluted concentration. The chloride response showed a weak positive correlation with discharge during low flow periods, implying that chloride moves mainly with the washout of the accumulated atmospheric deposition in forest vegetation. In runoff events, the concentration of 
potassium showed a positive correlation and that of sodium a negative one with discharge. On the other hand, the concentration of chloride had no apparent correlation with discharge. The response of potassium to runoff events indicated that the washout of the larger stock of potassium in shallow soil layers compared with that in deeper layers, and the response of chloride implied a simple washout effect of accumulated atmospheric deposition. The sodium responses suggest both the effect of ion exchange and the dilution of the base flow by rainfall, which have a higher ratio of sodium to chloride than that of the atmospheric input.

\section{ACKNOWLEDGEMENTS}

This work was supported by Grants for Scientific Research (11760172) by the Ministry of Education, Science and Culture, JAPAN. The authors gratefully acknowledge KURAHASHIGIKEN Company for design support throughout this work and for manufacturing the system. The authors also deeply acknowledge Professor Junji Hirama, Kanazawa Institute of Technology for providing the DCpowered amplifier.

\section{REFERENCES}

Alexander, P.W., Di Benedetto, L.T., Dimitrakopoulos, T., Hibbert, D.B., Ngila, J.C., Sequeria, M., and Shiels, D. 1996. Field-portable flow-injection analysers for monitoring of air and water pollution. Talanta 43: 915-925.

Arnold, J.G., Allen, P.M., and Muttiah, R. 1995. Automated baseflow separation and recession analysis techniques, Ground Water 33: 1010-1018.

Benson, R.L., Truong, Y.B., Mckelvie, I.D., and Hart, B.T. 1996a. Monitoring of dissolved reactive phosphorus in wastewaters by flow injection analysis. Part 1. Method development and validation. Wat. Res. 30: 1959-1964.

Benson, R.L., Truong, Y.B., Mckelvie, I.D., Hart, B.T., Bryant, G.W., and Hilkmann, W. P. 1996b. Monitoring of dissolved reactive phosphorus in wastewaters by flow injection analysis. Part 2. On-line monitoring system. Wat. Res. 30: 1965-1971.

Bowie, A.R., Achterberg, E.P., Sedwick, P.N., Ussher, S., and Worsfold, P.J. 2002. Real-time monitoring of picomolar concentrations of Iron(II) in marine waters using automated flow injection-chemiluminescence instrumentation. Environ. Sci. Technol. 36: 4600-4607.

Coles, S., Nimmo, M., and Worsfold, P. 2003. A portable flowinjection instrument incorporating a miniature spectrometer for the real-time monitoring of nitrate in rivers. Lab. Rob. Auto. 12: 183-193.

De Macro, R. and Phan, C. 2003. Determination of phosphate in hydroponic nutrient solutions using flow injection potentiometry and a cobalt-wire phosphate ion-selective electrode. Talanta 60: 1215-1221.
Dimitrakopoulos, T., Alexander, P.W., and Hibbert, D.B. 1996. A serial array of ISEs for use in a portable battery-powered flow injection analyzer. Electroanalysis 8: 438-442.

Gardolinski, P.C.F.C., David, A.R.J., and Worsfold, P.J. 2002. Miniature flow injection analyzer for laboratory, shipboard and in situ monitoring of nitrate in estuarine and coastal waters. Talanta 58: 1015-1027.

Hanrahan, G., Gledhil,G., Fletcher, P.J., and Worsfold, P.J. 2001. High temporal resolution field monitoring of phosphate in the River Frome using flow injection with diode array detection. Anal. Chim. Acta, 440: 5-62.

Ito, S., Kobayashi, F., Baba, K., Asano, Y., and Wada, H. 1996. Development of long-term stable reference electrode with fluoric resin liquid junction. Talanta 43: 135-142.

Kaneko, S. 1998. The wide area examination on torrent water in Kinki area; concerning the factors on formation of torrent water, Water Science 6(41): 35-55. (in Japanese)

Kennedy, V.C., Kendall, C., Zellweger, G.W., Wyerman, T.A., and Avanzino, R.J. 1986. Determination of the components of stormflow using water chemistry and environmental isotopes, Mattole river basin, California. J. of Hydrol. 84: 107-140.

Lyddy-Meaney, A.J., Ellis, P.S., Worsfold, P.J., Butler, E.C.V., and McKelvie, I.D. 2002. A compact flow injection analysis system for surface mapping of phosphate in marine waters. Talanta 58: 1043-1053.

Lyne, V. and Hollick, M. 1979. Stochastic time-variable rainfallrunoff modelling, I.E. Aust. Natl. Conf. Publ. 79/10: 89-83.

Motomozu, S., Oshima, M., and Ma, L. 1997. On-site analysis for phosphorus and nitrogen in environmental water samples by flow-injection spectrophotometric method. Anal. Sci. 13 Supplement: 401-404.

Muraoka, K. and Hirata, T. 1988. Streamwater chemistry during rainfall events ina forested basin. J. of Hydrol. 102: 235-253.

Stumm, W. and Morgan, J. J. 1996. Aquatic chemistry, $3^{\text {rd }}$ ed. John Wiley \& Sons: New York. 899.

Neal, C. and Kirchner, J.W. 2000. Sodium and chloride levels in rainfall, mist, streamwater and groundwater at the Plynlimon catchments, mid-Wales: inferences on hydrological and chemical controls. Hydrol. Earth Syst. Sci. 4(2): 295-310.

Robson, A.J., Neal, C., and Beven, K.J. 1995. Linking mixing techniques to a hydrological framework - An upland application. in: Trudgill, S.T. (Ed.) Solute Modelling in Catchment Systems, 1995, J. Wiley \& Sons: Chichester, 345369.

Rů žička, J. and Hansen, E. H. 1988. Flow injection analysis, $2^{\text {nd }}$ ed. John Wiley \& Sons.: New York

Tokuchi, N., Kuroda, Y. and Iwatsubo, G. 1991. Vertical changes of water-chemicals in a forest ecosystem (I) Vertical movement of $\mathrm{Cl}^{-}, \mathrm{Na}^{+}$and soil water in a sugi forest, J. Jpn. For. Soc. 73(2): 135-144 (in Japanese).

Tada, A., Horino, H., Watanabe, T., Hata, T. and Maruyama, T. 1996. Mass balance change in a catchment induced by land reclamation. Trans. of JSIDRE. 184: 13-22 (in Japanese).

Tada, A., Yoshimura, R., Tanakamaru, H. and Hata, T. 2006. Certainty in Estimation of Effluent Solute Load from Small Forested Catchment. Trans. of JSIDRE. 242: 39-48 (in Japanese).

Worsfold, P.J., Clinch, J.R., and Casey, H. 1987. Spectrophotometric field monitor for water quality parameters. Anal. Chim. Acta 197: 43-50.

Yuretich, R.F. and Batchelder, G.L. 1988. Hydrogeochemical cycling and chemical denudation in the Fort river watershed, central Massachusetts: An appraisal of mass-balance studies. Water Resour. Res. 24(1): 105-114.

(Received : Oct. 21, 2006, Accepted : Aug. 11, 2006) 


\title{
フローインジェクションポテンショメトリーを用いた山地小河川の
} カリウム, ナトリウム, 塩化物イオン濃度の高頻度・長期モニタリング

\author{
多田明夫1）田中丸治哉 1） 畑 武志 2) \\ 1)神戸大学農学部 \\ ( ₹657-8501 神戸市灘区六甲台町1-1) \\ 2)神戸大学名誉教授 \\ ( ₹606-0022 京都市左京区岩倉三宅町249-11)
}

高頻度の長期水質観測データは, 水文地球化学的なモデリングや非特定污染源のモデリングを発展させる上で, 水文データと共に久くことのできないデータである。このため，15分間隔で溪流水質（塩化物イオン，ナトリウム， カリウム）を2週間モニタリングできるフローインジェクションポテンショメトリー（FIP）オンサイト水質観測シ ステムを開発し，実験室と奈良県五條市に位置する小山林流域において性能試験を行った。本システムは冬期の試 料凍結を除いて，長期モニタリングを阻害する主要な要因を解決した。イオン選択性電極の温度依存性を補償する ために，3種の標準液による高頻度の校正試験が採用されている．実際の奈良県山林流域における2004年度のこれら 3種のイオンのモニタリング結果は,濃度の流量に対する応答がこれらの項目間で明らかに異なることを示していた. 塩化物イオンの応答は流域に堆積した大気からの沈着量を降雨流出が洗い出しているメカニズムを反映しており， カリウムの応答は降雨時に水分量が高まる土䁃の浅い層に蓄積されたカリウムの洗い出しを示唆していると思われ る.ナトリウムの応答にはイオン交換と化学的風化の両者の影響が認められた.

キーワード：オンサイトモニタリング，フローインジェクションポテンショメトリー, 渓流水質, 長期モニタリ ング, イオン選択性電極 